\title{
The Contribution of Public Libraries in Germany and the Nordic Countries Towards Digital Education and Training
}

\author{
Wolfgang Ratzek \\ Professor \\ Stuttgart Media University \\ Germany
}

\begin{abstract}
German school libraries, in contrary to the Nordic Countries, are few and far between. The number varies from region to region. IT tools and applications rule our daily life and the library world too, "E-learning", "Teaching Libraries", "Digital Library", and "Information \& Media Literacy" are of importance in Germany and the Nordic Countries. The Internet lay ground for cooperation between schools and public libraries. IT in general and the Internet in particular lay ground for cooperation between schools and public libraries. Library services, then, help students to perform better, e.g. by offering a multimedia based environment.
\end{abstract}

\section{Introduction}

Information and communication technology and its applications penetrate almost all facets of our individual and social life. No wonder that both the working world and the world of education exploit these technologies and applications to improve performance. As for education "E-learning", "virtual classroom", "Teaching Library", and "Library 2.0" are key words in this context.

This paper outlines the chances and problems for cooperation between school and public libraries in Germany and the Nordic Countries. Due to the federal structure, Germany has no library law, libraries are therefore heavily dependent on the goodwill of their financial backers. On the other hand, the Nordic Countries like Denmark, Finland, Norway or Sweden have one. As for Denmark, two laws are enacted: one for libraries, predominantly for public libraries, and one for school libraries. Furthermore, every school in Denmark is duty bound to run a library.

Libraries in the Nordic Countries are integrated in educational networks, German public libraries, in contrary, officially belong to the cultural sector and not to the education sector (often combined with the science segment). As the Nordic Country Denmark and South Korea, for example, provide special school librarian education or advanced school library training for teachers, Germany has no equivalent. German school libraries often are supervised by volunteering work provided by parents. Surprisingly, every school in the 20ties of the last century had a library on its own. This tradition is posted in the run of time.

These are some of the reasons why school libraries in Germany are few and far between. The number varies from region to region. Due to a long lasting lobbying the federal state Hesse and the Free State of Bavaria were able to increase the number of libraries in schools. Only the German "Gymnasium" (approx. High-School) and "Gesamtschule" (comprehensive school) often houses a school library on its own. Often, public libraries 
undertake this task of a school library. Hence, it does not surprise either, that the German system of education came off badly within the PISA survey. The potential of the Internet will helps to improve some of the problems mentioned above.

\section{E-learning - Part I: The Five Types of E-learning}

Many e-learning approaches incorporate digital versions of analogous media. Hence, they do not fully exploit the potential of digital media. Only digital media provide the opportunity that the object of perception can be transformed into an object of manipulation, sine qua non for shaping a virtual environment.

E-learning takes place as an individual action or as group activities at home, in virtual classrooms or in libraries. Far-off being trivial are the different types of e-learning which librarians have to understand if they want to support e-learning processes in education and training. There are at least the following five types of e-learning with a need of various media and technologies:

- Strict learning supports self-determined individual or group learning. Strict learning means that learners need a special e-textbook, a special learning software or access to the Internet ("Wikipedia" or Ask a Librarian) for support with homework. (School) libraries, in that case, offer a wide range of solutions for strict learning, reference on- or offline service and a learning-supporting atmosphere inclusive.

- Blended-Learning-arrangements are based on a mixture of best and effective elements of classic classroom teaching (social behavior) and the best and effective elements of elearning (information and media literacy). It aims at solving problems in web supported cooperative work (collaboration tools). The Norwegian based Fronter is one of Europe's leading provider of „online e-learning management solutions“, often called „Virtual Learning Environments (VLS)" or "Learning Management Systems" (LMS). Via Fronter's "Open Source Learning Platform and Personal Learning Environment" (PLE) approx. 90 easy top use Web tools which are selected carefully by a reference group. More than 1000 educational institutions uses the platform, thereunder, colleges, public authorities, and schools. Fronter's motto is: 'Knowledge through Collaboration' by offering a state of the art web based and multilingual VLE where students and learners alike can benefit from collaboration and learning." Fronter received numerous prizes like the CEBIT Innovation Prize „European Seal of Excellence in Multimedia in Gold“ (2004 and 2006), (awarding criterias: innovation, performance, usability, social benefits), In December, 2006 Fronter received the „Becta Learning Platform Service Accreditation“, awarded by the British Educational Communications and Technology Agency (Becta) . (Ratzek 2007, p. 63)

- Communication- and cooperation tools (Social Software) self-contained effective programs like e-mail or Instant Messenger programs (icq, Skype) or collaboration tools (Groupware). In this context the Web 2.0 or Social Software (Tagging, mash-ups, podcats) come into play (see above: Library 2.0 and eTwinning).

- Simulation and (Learning) Games represent a promising area of application for competence development in schools. Due to the dynamic of computer technology and its periphery this category is on the upswing and meanwhile spread on a large scale. The following two examples might stress this development: The Norwegian platform matematikk.org provides service for the target groups teacher and parents and a separate clusters for children aged 5-10, 10-13, and a special clusters for students at comprehensive school and High school. The services are free of charge. The project is 
carried out by a team of seven scientists, instructors or textbook author from Norwegian Colleges or Universities. The interactive platform offers age-based interactive services like "Su Doku" (10-13) or a collection of interactive games for students of all age. The idea behind Danish project "Enter X" (www.enterx.dk) is to develop an online learning game for children to improve their information competencies. Danish school librarians and Copenhagen and Odense Country libraries launched "Enter X". They found out that children waste a lot of time searching for information on the Internet. Typical Web 2.0, the beta version of Enter X are made available in 2006. The project Enter X is based on a cooperation between DotBot, Odense Centralbibliotek (Odense Central Library), and "Kommunernes Skolebiblioteksforening (The Commune School Library Association - a publishing house!). The financing is guaranteed by "Biblioteksstyrelsens" (The Danish Library Agency). Possible search requests (called "inspirations") are "Da Vinci Code Web quest", "Games for the brain", "Spy Academy" or "Treasurehunt". The target group are schoolchildren aged 9 to 12 years. "Enter X - Development of net based e-learning application for children" (Scandinavian Public Library Quarterly, 2006, p. 25) The Multimedia Playground: The City Library in the city of Bremen (Northern part of Germany) started, in the children's and junior library, a new course by its "MultiMediaPlayground". Everyday a selection of standard programs of computer games are available for the target group. In case of a performance 11 more multimedia computers stand by. Twice a week twelve to sixteen year user get access to age-based computer games. Computer games, today, are artistically and technically qualitatively high grade products. To give the user a deeper insight, the library offers events, where they meet game designer and programmer who inform the target group about content, technical and graphic development of games. On June 24, 2006 the City Library Bremen received for this new service the AOL-Media award.1

- Informal learning stands for an important strategy in the information and knowledge society (Informal learning must be included in intended learning and (media) educational arrangements, an aspect we often neglect in our strategy. Due to the accessibility of information and communication technology, especially the Internet, informal learning is of importance, not only in an adult context ${ }^{2}$, but also for students in elementary schools or high schools. In addition to traditional school learning, out-of-school place learning come into our field of vision, e.g. in public libraries, on Internet, in clubs, or private lessons. The German ,e-Lernbar“ (the e-LearningBar: http://www.zlb.de/wissensgebiete/elernbar) provided by The Central and State Library in the City Berlin defines itself as a place for communication and imparting knowledge. Each patron with a valid borrower's ticket of the VÖBB (Verbund Öffentlicher Bibliotheken Berlin; the Public Library Network of Berlin) gets access to the "e-LernBar". The e-learn bar offers numerous free self-learning course. At the moment the following learning programs are made available:

- Language (German, English, Spanish)

- MS Office (Word, Excel, Access, PowerPoint, Outlook)

- Image editing (e.g. Photoshop CS, Corel Draw 8.0)

- Internet (e.g. JavaScript, Flash MX, HTML)

- Data bases (e.g Lotus Notes)

- Windows XP

\footnotetext{
${ }^{1} \mathrm{http}: / /$ www.stadtbibliothek-bremen.de/index.php?navi=content\&lang= 1\&npoint=2,130,203,0.

2 "Obwohl etwa 70 Prozent der Lernprozesse Erwachsener außerhalb von Bildungsinstitutionen stattfinden (z. B. Faure 1972, Livingstone 1999: ).”(Livingstone, D. W. (2006): Informal Learning: Conceptual Distinctions and Preliminary Findings. In: Bekerman, Z./ Burbules, N.C./ Silberman-Keller, D. (2006): Learning in Places. The Informal Education Reader. New York u.a.: Peter Lang, S. 202-226)
} 
On two Photoshop carrels patrons may edit their picture. Printer and Scanner are available too. Furthermore, online search can be carried out in various ZLB data bases.

\section{E-Learning - Part II: The E-learning Program for Europe}

(Online) communities are one important success factor for e-learning. They represent virtual meeting places, or better: cross-border virtual platforms for individuals with equal interests. Students may exchange information and share knowledge and experience among each other in a comfortable way. The growth of content and the dynamics of learning processes are determined by the learner themselves. In this context the competence and personality of the instructor, or better the coach come into play. Community-based e-learning differ from traditional e-learning by new methods of learning instead of prefabricated learning offers.

The Heads of State and Government of the European Union (EU) formulated their aim in the Lisbon declaration of 2000 that Europe by 2010 will be "the most competitive and dynamic knowledge-based economy in the world, capable of sustainable economic growth with more and better jobs and greater social cohesion". (European Commission, 2003, p. 1) In this context, the European Commission wishes to renew European's education and training system. Without infrastructure, equipment, and content, a knowledge-based society will not come true. The aim of "eLearning Action Plan" of the EU was to increase the number of school with access to the Internet and Internet connected computers. According to a EU statistic, representing March 2002, in Germany (99\%), in the Nordic Countries: Denmark (100\%), Finland (99\%) and Sweden (99\%) of all school had access to the internet. In addition to this figures more than $50 \%$ of "Europe's teachers have been trained in the use of computers and/or the Internet. (ibid., p. 4)

As the best ICT is of no use without content, we now present some school related EU projects. Let us start with the following three projects:

E.L.I.Fo - e-learning intercultural Forum. It "provides a virtual forum for teachers and trainers for intercultural programmes that offer disadvantaged people training in social and professional integration." (ibid., p. 7)

LEIPS - Learning about e-learning Innovation process in Schools. LEIPS "will monitor the e-learning innovation area and identify best practice, disseminate various training materials as well as create a network to transfer the best practice results" (ibid., p. 7)

The European Schoolnet "is an all-encompassing network bringing together 23 Ministries of Education throughout Europe and linking schools, teachers and school managers.( ibid., p. 11) Two of the project and initiative are mentioned here: The "Virtual School" focus on "online learning resources, tips and activities in curriculum subjects." (ibid.). The "European Network of Innovative Schools links front-running establishments to share practice and test new learning technologies." (ibid.)

Since the start of the eTwinning program ${ }^{3}$ in 2005 more than 13,000 schools have been integrated in collaborative project. Here are some projects, taken form the eTwinning data base, with German and Nordic participants:

\footnotetext{
${ }^{3}$ http://www.etwinning.de/projektdatenbank/index.php.
} 
- The "Art Net": Ten schools from European countries take part in the "Kunstnetz" project. The Berlin based "Siegerland elementary school" and the "Søndervangskole" from Denmark contribute to the project which. Two key features are essential: Organizing an internet exhibition showing pupil's work created in art classes (class 1-13) and to practice multimedia based techniques to overcome language barriers. Visitors of the virtual exhibition may comment via a weblog.

- The German "Möörkenschule" in the city of Leer and the Norwegian "Vassmyra ungdomsskole" seem to be one of the most active contributors. Here are some examples of their cooperation: A young tribute to Peer Gynt: The students of both schools interpret some scenes of the dramatic poem „Peer Gynt“ written by the Norwegian dramatist Henrik Ibsen. Later on they implemented the scenes chosen into a multimedia based work of art, a synthesis of music, pictures, poems, text, and video clips. English was the language they used for understanding each other. Cooperating on creating digital multimedia based expressions: In their Norwegian lessons each student got a word charged with emotion. The Norwegian student, now, had to write a poem or had to capture the word in a picture. The results were sent to the German class. The German students, then, had to add music to the art work. After this, everything was put together in multimedia base show. Students have many languages: Each student interprets a word by a picture, a self-written poem poem, an a bit of music. The poem is composed in both English and in the corresponding national language. The German students, finally, prepare a multimedia-based presentation.

- The Berliiniprojekti conducted by the German „Merian Oberschule“ (a high school) in the city of Berlin and the Finnish „Tiirismaa Comprehensive“: The students of both countries made themselves familiar with the corresponding culture via e-mail and school trips. The results are published in form of a web magazine which demands skills, among other thing, in internet text writing, image editing, layout.

- Germany and Sweden - let's get acquainted! The German "Mittelschule Bad Gottleuba" and the Swedish "Trönningeskolan" first started communication via e-mail to get information about the contact person, her family, her hobbies, her hometown and its environment. In the meantime a regular information exchange exists. A chat platform or video conferences are considered.

- A Recipe Book from Kimito and Bochum: The German „Graf-Engelbert-Schule“, and the Finnish „Kimitonejdens Högstadiet“ have been in contact since 1997. In 2003 they compiled a recipe book in German and Finnish. The results were presented on the web sites of both schools.

- SweGer Magazine - the Swedish/German online student's magazine. The German „Europaschule Ketzin“ and the Swedish „Ormstaskolan“ published an online-student”s magazine for the Internet platform Magazine Factory. The magazine contained, among other things, personal profiles, school formality (schedules, school subjects, clubs, school logo), and news, Sudokos, leisure activities, and a trilingual dictionary (English, German, Swedish).

- World Wide tWinning Christmas traditions. 33 schools from 17 countries, among them schools from Germany (1) and the Nordic Countries (8), took part in this project. The aim was to produce an interactive Christmas calendar. All participating classes invented a Christmas related story based on tradition of their homeland, written in English. Each story was linked to a calendar window. 


\section{Two Innovative Schools}

The German Phorms AG represents a new type of schools in Germany. Phorms AG might revolutionize the German school system. In the first place this Berlin based elementary school operates under the legal form of an incorporated company. In other words: a profit seeking institution. Secondly, all class rooms are equipped with computers, e-learning software and Smart Boards. Only a few schools in Germany can keep up with such a setting. The Phorms AG started in August 2006 in Grade Reception-5 and will add a grade six to the Primary School in August 2007, at the same time the secondary school will open with Grades 7 and 8. Phorms plan to open schools in Munich, Hamburg and Cologne.

Virtual classrooms: Germany - export champion - deliver goods and expertise around the world. This means, that many experts have to move abroad along with their family, e.g. to East or South Asia. Parents as well their children are often confronted with a problem: How to organize school attendance on the spot? German affiliated companies, pedagogue, and the national supervisory (school) authority are planning an innovative project that will arouse worldwide interest in professional circles. German schoolchildren in remote areas of East and South Asia attend their classes in Germany every day by a video live transmission. By this means they will even be able to graduate from high school. Parents and their schoolchildren are now profiting from the adoption of the virtual organization, realized in the business world and R\&D. The ICT necessary will be provided and financed by German companies (a Private-Public-Partnership). To begin with a leased line to China will be implemented. The students will attend a class which corresponds with their time zone. In this way, they are able to attend a math class in real time. On site teachers or parents are supervising the school children. Before the school year begins, the student is visiting his/her "virtual school" and meets his real schoolfellows. The companies based in the cities of Wolfsburg (VW), Cologne (Ford) and Shanghai and Changchun (physical company school of VW). In the long run all German school abroad, e.g. the German European School in Singapore, may be integrated in a virtual network. In that case a German student located in Singapore may attend Latin class in the city of Tokyo and a German student located in Delhi will attend as Spanish course in Singapore. (F.A.Z., 2006, p. 13)

\section{Web 2.0 and Social Software}

The meaning behind Social Software or Web 2.0 becomes clear by trying it out. This collaborative software enables non-techies to shape the web by setting up a weblog or a wiki, by broadcasting yourself (You Tube), by releasing a mash-up of your own.

As competition does not sleep, see Google Book Search (http://books.google.com/) or LibraryThink (http://www.librarything.com/) a platform for connecting readers by offering various services like a "Virtual Shelf", "Blog", "Book Suggestions", librarians have to meet the challenge. But can we transfer the Web 2.0 philosophy into a Library 2.0 philosophy? The answer is yes.

No doubt, new generation of library users is/will be the net generation and the expectation of this target group toward a library (will) cause a great impact on librarian's role. 


\section{Library 2.0}

Library 2.0 represents a new concept for libraries. Apart from the deeper technological implications like SOA (Service Oriented Architecture), we will now concentrate on the application level which refers to the collective term "Social Software".

To show the difference between the Library 1.0 and Library 2.0, Jack M. Maness (2006) provides the following list of examples:

- „Email reference/Q\&A pages $\rightarrow$ Chat reference

- Text-based tutorials $\rightarrow$ Streaming media tutorials with interactive databases

- Email mailing lists, webmasters $\rightarrow$ Blogs, wikis, RSS feeds

- Controlled classification schemes $\rightarrow$ Tagging coupled with controlled schemes

- OPAC $\rightarrow$ Personalized social network interface

- Catalog of largely reliable print and electronic holdings $\rightarrow$ Catalog of reliable and suspect holdings, web-pages, blogs, wikis, etc." (Maness, 2006)

In other words: Librarians have to recognize that the out-dated Library 1.0 philosophy is based on searching, whereas the Library 2.0 is about finding and user-centered interaction. Furthermore, Library 1.0 services are based on providing access, whereas the Library 2.0 is about sharing information and knowledge. (Maness, 2006).

By means of Social Software the Library 2.0 offers user-centered user-centred interactive internet services like weblogs, RSS-feeds like www.lisfeeds.com (replacing inconvenient web search), mash-ups, or podcast/vidcast. (Danowski \& Heller, 2006, pp. 1259-1271; Maness, 2006).

No doubt, libraries start using the Web 2.0 to renew and improve their services in form of wikis, weblogs, mash-ups, tagging, platforms for exchanging pictures or videos. Since we are focusing on Germany and the Nordic Countries, we are now presenting some examples

\subsection{General Projects}

- The German Saarland University and State Library replaced, in spring 2006, its information ,systems (intranet, network drives, e-mail program, telephone) by ISIS. ISIS represents a overall system by integrating the departmental-covering contentmanagement-system Plone, an open source product with a Zope based Wiki (Zope: a platform for web application).

- In the city of Gouda (The Netherlands) there is a close cooperation among the City library, the regional archive (Streekarchief Midden-Holland and the Museum of Gouda. This cooperation forces these institutions to seek for innovative methods of information and communication within the institutions and for the borrower, user and visitors. The aim is to implement and digital information environment for mutual relations which could be worked up to a platform for cultural development. Aquabrower, an associative search engine, provides access to all three catalogs (www.goudanet.nl). In collaboration with the citizen of Gouda a digital dossier of their city will be worked out. 


\subsection{Special Library Projects}

- The German mash-up service Karlsruhe Virtual Catalog Recommender (RE-KVK) represents the next step of evolution within Library 2.0. The KVK (http://www.ubka.unikarlsruhe.de/kvk.html) is a meta search interface which allows you to access library and book trade catalogues worldwide. The evolutionary steps are the adoption of an OPAC RSS-Alerting Service (same service planed for KVK too), the introduction of a Recommender-Service (RE-KVK) which then lay ground for automatic indexing. REKVK "recognizes" the information need of a patron and offers besides a hit-list a number of related literature. . KVK is a pioneer in the field of virtual library services.

- Both in Germany and the Nordic Countries internet portals for school librarians do play an important role for a nation wide and fast information exchange, e.g. the German portal schulmediothek.de., the Norwegian portal skolenettet.no, the Swedish portal skolbibliotek.se or the Danish class portal emu.dk. EMU, for instance, started in 1999 as an electronic meeting place. In cooperation with the Danish Department of Education and the University of Copenhagen. emu.dk, today, provides content for schoolchildren, students, teachers, parents, other person interested in education and training.

\subsection{Blogs for Librarians}

Google, of course, gets in on everything and now in library matters too. Google launched the blog "Librarian central" (http://librariancentral.blogspot.com/). Another international known blog, written by and for librarians, is "biblioblogsphere". Looking towards Northern Europe we will find some library blogs too. Here are four examples:

The German working group "One-Person-Library Berlin-Brandenburg" set up a professional weblog, which serves as a content management system. The working group is a open association of libraries of academic, cultural, educational institutions or of public authorities or museums. All members have to handle the information and document management of their institution. In addition to the regular meetings and a mailing list the weblog serves as a platform for information and exchange of practical experience, as well as for documentation of activities, and for public relations reasons.

The Danish "Biblog: Fremtiden er digital!" (Biblog: The Future is digital!). This blog provides news from the IT and library world. It shows the changing role of librarians.

We have only seen the top of the technological iceberg. This blogs provides news from the IT and library world as well as news from the area of conflict: the old and the new world of libraries. (http://bib-log.blogspot.com/)

The German "netbib weblog" (http://log.netbib.de/). Netbib is hosted at the Dortmund University library. This blog offers a special Web 2.0 specialty: a interesting tag cloud (Tagging).

The slogan of Norwegian "Blogg og Bibliotek" ("Blog and Library; www.bloggbib.net/) uses the slogan "Bibliotek, Bibliotekarer, Tanker og Meninger" (Library, Librarians, Ideas, Comments). The weblog specializes in library policy and technology. 


\subsection{Blogs for Lecturer and students}

A very creative and innovative weblog project was set up at the University of Iceland. Students in the "Computer and Libraries" courses created "ComLib", a weblog about websites containing information on information technology in libraries. Unfortunately, the team members only were aloud to post messages to the weblog. (Clyde, 2004, p. 12)

The "EdBlogger Praxis"( http://educational.blogs.com/) records a number of examples of collaborative weblogs in elementary and secondary schools, serving a variety of instructional purposes. (Ibid.)

\section{The Role of Librarian in the D-World!}

Within the D-world the Internet provides a new dimension to education with far reaching possibilities. The WWW, Google, Wikipedia, and the "copy and paste" keys might be the most used tools or applications for almost all kind of students. If we do not accept these trends as wonder remedies for obtaining information and media literacy, than we have to ask ourselves what are the librarians' unique selling propositions? In what way, do public libraries support schools to perform better? The answer sounds like this: Libraries of all kind provide a comfortable physical and multimedia based environment in which target groups like students of all ages may improve their literacy in general and their information and media literacy in particular.

Libraries can only fulfil this claim if we are familiar with the media offered, that we know how to profit from a retrieval strategy, and that we are able distinguish between relevant and irrelevant information, and, furthermore, between fact and opinion. In this context the teaching library philosophy comes into play which especially in Germany this concept is actually of importance (Lux \& Sühl-Strohmenger, 2006).

The mission of a teaching library is to provide resources and services for the promotion of information and media literacy. How use of information in a creative and an ethical way Libraries in this context are catalyst for the evolution of a democratic organized information and knowledge society.

The UNESCO School Library Manifesto/IFLA-Guidelines provides a good basis for user training within a teaching school/public library. User training in school libraries take the following three key issues into account:

- Knowledge on the library in general: Mission, Services, Organization

- Skills search strategies and use of information

- Motivating students to use the library for formal and informal learning. (Lux \& SühlStrohmenger, 2006, p. 161)

Information and media literacy empowers school children by imparting essential skills for information problem solving. They support people, e.g. students, to recognize how to get access to information resources of all kind and forms. This implies imparting knowledge like 
- retrieval techniques

- how information is created, evaluated, and disseminated

- recognize one's need for information and how to satisfy it by/through effective retrieval technique

- know how to handle multiple formats and how to access to the different sources.

Being a teaching library implies a broad range of commitments like,

- Infrastructure e.g. teaching staff, training classroom(s) equipped with multimedia,

- Teaching offers e.g. general orientation, library tour, programs for elementary schools, for high schools

- E-learning e.g. screen scanning, e-tutoring, learn platform, starter kit (DVD)

\subsection{The Virtual Library}

The Internet, or better: the World Wide Web provides a comfortable access to information anytime, anywhere, any place. Full texts of all kind can be downloaded in real time and ready for electronic processing.

3-dimentional semantic networks (a formal model of terms and relations) called ontologies, like the German LIS-ontology "Dandelon" (www.agi-imc.de/isearch/is_dgi.nsf), support navigation within information explosion. Seen from a librarian's point of view, Library 2.0 will turn the beloved library taxonomies (classification, thesauri) into a Folksonomy.

At the moment libraries have one all-dominant advantage over the Internet: Libraries dispose of media of all kind and on a big scale and of high quality which cannot be found on the Internet. The Big Shots in the information economy threaten this business model - for money of course. The Bavarian State Library joins the Google library project. Within the project Google will digitize all books with expired copyright for Google Book Search. Google aims at making the printed knowledge of the entire world searchable on the Internet. Numerous university libraries (e.g. Harvard, Oxford, Princeton) are already taking part in this project.

Digital Virtual Library (Germany): If public libraries do not want to lose more patrons they have to transfer their model of media loan into the Internet and expand to digital content. Such a project can be handled only in a joint operation with a service provider. In this case, public libraries cooperate with DiViBib GmbH (http://www.divibib.com/). The City Library in the city of Cologne serves as a pilot library.

Virtual Reference Service: Knowledge nurture information in learning processes. Libraries represent meeting places and places for individual and collaborative acquisition of knowledge. Besides access to media of all kind, libraries, at the same time, are skilled in selecting, structuring and mediate information. As (lifelong) learning takes place anywhere, anytime, anyplace librarians have to be prepared to support in solving their information problems. Libraries offer, therefore, various forma of reference services: besides the face-toface-service, we find e-mail based reference services, web-templates based services. Occasionally the learner is confronted with virtual agents (Avatar) like the two German library avatars "Stella", provided provided by the State and University Library Carl von 
Ossietzky in the city of Hamburg 4, and "INA" provided the "Hamburger Öffentliche Bücherhallen" (HÖB - the Public Book Halls of Hamburg) [http://www.buecherhallen.de/].

A cooperative reference service within a (school) library network will optimize the traditional reference service on site. The virtual reference service of the BSZ, The Bibliotheksservice-Zentrum Baden-Wurttemberg (Library Service Centre), provides information for all libraries. (http://www2.bsz-bw.de/cms/index_html). „DigiAuskunft“" stands for another virtual reference service, provided by ,hzzb“, Hochschulbibliothekszentrum des Landes Nordrhein-Westfalen (University Library Center of the (German) federal state North Rhine Westphalia. The system is based on two open source components: an e-mail module (Software OTRS, also implemented by DaimlerChrysler and NASA) and a chat module. A real time reference service is organized by the chat module RAKIM.

The next generation of reference services might be a mobile one respectively a mobile information transfer. One of my students told me once: „The technology I want most is a PDA device that contains all the information I need to do my work. "Libraries have to face this kind of claims.

Libraries pay attention to dyslexic person: Dyslexia is an impairment of the ability to read, as a result of a variety of pathologic conditions, some of which are associated with the central nervous system. Dyslexic persons often reverse letters and words, cannot adequately distinguish the letter sequences in written words, and have difficulty in understanding left from right. Voiceeye (www.voiceye.com/) could be a intelligent library service for dyslexic persons. Voiceeye, also called: audible paper, is universally designed for people who are blind, visually impaired, partially sighted and illiterate to access information in all printed materials. Voiceeye, developed by the South Korean based AD Information \& Communications Co., Ltd. is the one which is able to store the largest amount of data among 2D bar codes in the world. Actually 5,000 bytes of data can be stored in the size of 1 square centimetre. The following features are included: Advanced real-time Text-to-Speech reader, audio book (storing about 420 books), built in voice recorder, built in MP3 player, FM radio, Talking clock, Name card \& address book.

Talking about the D-world or Cyberspace, we sooner or later run into Second life (http://secondlife.com/), the "3D Online Digital World. Imagined, Created \& Owned by its Residents". Many universities and some libraries are already present in SL, e.g. Allicance Library System (East Peoria, Illinois, USA) or the Public Library of Charlotte and Mecklenburg County: Charlotte, North Carolina, USA. State Library of Kansas. ${ }^{5}$ Furthmore, Second Life offers a wide range of "Teen Educational projects", e.g. Teen Educators in SL (TED) "is a collaborative community of real life educators seeking to support, inspire and train other teachers interested in using the Teen SL interface to educate students ages 13-17. Teen Educators in SL have a presence in Cybrary City on the Main Grid. Cybrary City offers physically distributed groups an opportunity to come together to share their ideas and experiences." ${ }^{6}$ Under the heading we find the "Teen Second Life Educational Projects":

- The campus EdBoost: A "TSL project where students script the contents of the island and adults teach computer programming".

\footnotetext{
${ }_{5}^{4}$ http://www.sub.uni-hamburg.de/informationen/projekte/ infoass.html.

${ }^{5}$ www.simteach.com/wiki/index.php?title=Institutions_and_Organizations_in_SL\#LIBRARIES.

${ }^{6} \mathrm{http} / / /$ www.simteach.com/wiki/index.php?title=Second_Life:_Educators_Working_with_Teens.
} 
- The Global Kids Island: "A place for teen residents ${ }^{7}$ to learn about important social and world issues. The island recently hosted (winter, 2006) a digital media essay contest, the SL version of the Save Darfur charity wristband campaign, a photo show from Global Kids Leaders, Camp Gk (summer, 2006, Fall 2006 UNICEF A World Fit For Children Festival, the Henry Jenkins lecture/dance party, and interactive, experiential workshops led by GK staff on issues related to digital media. In the fall of 2006, a real world machinima program and a real-world gaming program, both using TSL, were launched in NYC. Information about all of these projects - teen posts, comics, video, press coverage and more - available at our web site".

- The Eye4YouAlliance: "A partnership with the Public Library of Charlotte and Mecklenburg County and the Alliance Library System to give opportunities to teens to create and collaborate through library services offered in Second Life."

- The Kids Connect Island (teen grid).: A "series of workshops for young people in multiple locations, teaching them to connect and work together via performance, storytelling and collaboration by both theatrical and digital means... Guided by artists and educators from theatre and new media, they learned skills like VJ-ing ${ }^{8}$."

- The Playback Theatre focuses on "digital storytelling, and 3D modeling. In teen SL, they met and collaborated to build a hybrid city combining aspects of both New York and Amsterdam. Within that common space, they created a performance that occurred both live and online simultaneously. "

- The Pacific Rim Exchange or PacRim X "is a collaboarative project between two school districts, one in California, and one in Japan. The island will be private and only open to exchange students from the two school districts, and their teachers. The blog will catalog the progress of the project."

- The Suffern Middle School: "A virtual presence for education at Suffern Middle School, Suffern, NY."

\section{Final Remarks}

Only a small percentage of all schools in Germany, in contrary to the Nordic Countries, houses a library and many do not meet the expectation of a multimedia and educational library, i.e. carrels for schoolchildren, computer, digital catalog. Public libraries, then, undertake the task, often with volunteers. On closer inspection, we will find some highlights anyway. Against the background of the Web 2.0 hype, the set up of an social (digital) network will be one of the great challenges (school) libraries have to face. Whereas, in the traditional library/Web 1.0, "perpetual beta" (O'Reilly) stands for "unfinished" or "under construction", "perpetual beta" in the Web/library 2.0 philosophy signals that a continuous improvement process is going on to keep abreast with the state-of-the-art. In other words: "perpetual beta" is a quality feature.

\section{References}

Danowski, P. \& Heller, L. (2006): Bibliothek 2.0: Die Zukunft der Bibliothek. Bibliotheksdienst, 11, 1259-1271. Clyde, L.A. (2004) : Weblogs for Libraries. Oxford, Hampshire.

European Commission (ed.) [2006]: eLearning. Better eLearning for Europe. Brussels 2003. F.A.Z. (2006): Video-Unterricht für deutsche Schüler im Ausland (2006-12-05), No. 283, p. 13

\footnotetext{
7 Teens have "no" access to the adult SL (who checks this?), therefore a special teen grid is set up.

${ }^{8} \mathrm{VJ}$-ing (Video jockeying, but also visualization of music).
} 
Livingstone, D. W. (2006): Informal Learning: Conceptual Distinctions and Preliminary Findings.

Bekerman, Z., Burbules, N.C., Silberman-Keller, D. (2006): Learning in Places. The Informal Education Reader. New York [et.al], S. 202-226.

Lux, C. \& Sühl-Strohmenger, W. (2004): Teaching Library in Germany. Wiesbaden 2004.

Maness, J. M. (2006): Library 2.0 Theory: Web 2.0 and Its Implications for Libraries. Webology, (http://www.webology.ir/2006/v3n2/a25.html; 7.3.2007).

Modellprojekt: Video-Unterricht für deutsche Schüler im Ausland. F.A.Z., 2006-12-05, № 283, p. 13.

Rasmussen, B: Internettet for børn og unge - nye formidlingsformer. Skolebiblioteket 10/2006, pp. 16-18.

Ratzek, W. (2007): Trends in der eLearning-Branche. B.I.T.online, 1, 62-63.Scandinavian Public Library Quarterly (2006): Enter X - Development of net based e-learning application for children, 1, p. 25.

\section{Author Note:}

Wolfgang Ratzek, holds a master's degree in Information Science and Scandinavistics as well as a $\mathrm{Ph}$.D. in Information Science. After professional experience in the field of marketing, management and personnel he was appointed to a professorship at the Stuttgart Media University/Germany, where he teaches Business Administration, especially Marketing and Human Resources Management. He published numerous papers. 